\title{
Gonadotrophin-induced accumulation of 'interstitial fluid' in the rat testis
}

\author{
R. M. Sharpe \\ M.R.C. Unit of Reproductive Biology, 2 Forrest Road, Edinburgh EH1 2QW, U.K.
}

\begin{abstract}
Summary. 'Interstitial fluid' containing high levels of testosterone $(60-250 \mathrm{ng} / \mathrm{ml})$ was recovered from the testes of rats, the amounts increasing with increase in age and testis weight. Injection of $170 \mathrm{i} . \mathrm{u} . \mathrm{hCG} / \mathrm{kg}$ resulted $20 \mathrm{~h}$ later in significant increases in interstitial fluid and its testosterone content $(300-800 \mathrm{ng} / \mathrm{ml})$. In immature rats this effect of hCG was dose-dependent and time-related and the accumulated fluid contained high levels of potassium and phosphate; levels of sodium, calcium and protein were similar to those in serum. At $20 \mathrm{~h}$ after injection of hCG, other testicular changes were (1) increased 'adhesiveness', (2) reduced in-vitro binding of ${ }^{125} \mathrm{I}$-labelled hCG, and (3) an hCG-induced increase in the testis:blood ratio of hCG in vivo.
\end{abstract}

\section{Introduction}

Injection of male rats with human chorionic gonadotrophin (hCG) or luteinizing hormone (LH) results in a prolonged decrease in testicular LH (hCG) receptors (Hsueh, Dufau \& Catt, 1976; Sharpe, 1976; Haour \& Saez, 1977; Purvis, Torjesen, Haug \& Hansson, 1977) and, in certain circumstances, a reduced capacity of the testis to secrete testosterone (Hsueh et al., 1977; Sharpe, 1977a). In the immature rat, injection of hCG also results in a transient but substantial $(20-35 \%)$ increase in testicular weight due to the accumulation of fluid (Sharpe, 1977b). The present paper describes this effect in more detail in rats of different ages, and attempts to relate 'interstitial fluid' accumulation to other changes induced by hCG treatment.

\section{Materials and Methods}

The animals were from our inbred strain of $\mathrm{L} / \mathrm{H}$ rats and were housed as described previously (de Jong \& Sharpe, 1977). At 22 days of age male rats were injected subcutaneously with 10, 1 or 0.1 i.u. hCG (Chorulon: Intervet) in $0.5 \mathrm{ml}$ saline $(9 \mathrm{~g} \mathrm{NaCl} / 1)$, and killed with ether 20 or 48 $\mathrm{h}$ later, when testicular 'interstitial fluid' was collected as described below. Similar procedures were followed when male rats aged $35,50,70$ or 200 days were killed at $20 \mathrm{~h}$ after injection of hCG $(170$ i.u. $/ \mathrm{kg})$ at a dose roughly equivalent to the 10 i.u. given to the 22 -day-old rats. For all the groups equivalent numbers of saline-injected control rats were used.

\section{Measurement of 'interstitial fluid'}

The paired testes from individual rats were removed, cleaned of extraneous material, placed into pre-weighed 5-ml plastic serum vials and weighed. A small incision was then made in the caudal end of each testicular capsule, the testes were replaced in the vials and the interstitial fluid was allowed to collect in the bottom of the vial kept for $4 \mathrm{~h}$ at $4^{\circ} \mathrm{C}$. The testes were then removed and the fluid remaining in the vials was weighed and stored at $-20^{\circ} \mathrm{C}$. When thawed, the 
fluid was centrifuged for $5 \mathrm{~min}$ at $1500 \mathrm{~g}$ and $0.1 \mathrm{ml}$ of the supernatant was removed and diluted with 0.01 M-phosphate-buffered saline ( $\mathrm{pH} 7.5$ ) containing $0.1 \%$ gelatin (Sigma). Testosterone was then measured by radioimmunoassay as described by Corker \& Davidson (1978) except that samples were assayed directly, as interstitial fluid from hCG-treated rats had previously been shown to give comparable results $(\mathrm{N}=12, P>0.1$ by paired $t$ test) before and after extraction with 10 volumes of hexane : diethyl ether $(4: 1, \mathrm{v} / \mathrm{v})$. Unextracted interstitial fluid from control and hCG-treated adult rats gave dose-response curves which were parallel to the standard curve $(P>0.05$ in a test of non-parallelism by two-factor analysis of variance) over the range tested $(0.1$ to $0.01 \mu$ equivalents of interstitial fluid). In the present study all samples were assayed together at doses in the range 0.1 to $0.02 \mu \mathrm{l}$, and the intra-assay coefficient of variation was $\pm 4 \%$. Other details of the assay method and separation procedure were as given by Corker \& Davidson (1978). The sensitivity of the assay was $120 \mathrm{pg} / \mathrm{ml}$. Quantitative assessment of the concentration of various non-hormonal factors in interstitial fluid and serum from immature hCG-treated rats was kindly performed by $\mathrm{Dr}$ J. Seth using a computer-linked Technicon sequential autoanalyser.

\section{Binding of ${ }^{125}$-labelled $h C G$}

After the above procedures, testes from control and hCG-treated rats were decapsulated and homogenized, and the in-vitro binding of ${ }^{125}$ I-labelled hCG was determined as described previously (Sharpe, 1976) using $20 \mathrm{mg}$ homogenate and $15 \mathrm{ng}{ }^{125} \mathrm{I}$-labelled hCG/ml for incubation. The hCG (CR 119; 11600 i.u./mg) was labelled with ${ }^{125}$ I by the method of Miyachi, Vaitukaitis, Nieschlag \& Lipsett (1972) to a specific activity of $64 \mu \mathrm{Ci} / \mu \mathrm{g}$. The in-vivo testicular binding of ${ }^{125}$ I-labelled hCG was assessed as described previously (Sharpe, 1976) following injection of rats aged 25,60 or 120 days with $10 \mathrm{ng}{ }^{125}$ I-labelled hCG $(0 \cdot 12$ i.u.) alone or together with 10 i.u. unlabelled hCG in $0.2 \mathrm{ml} 0.01 \mathrm{M}$-phosphate-buffered saline.

Isolation of Leydig cells from the testes of saline- and hCG-treated immature rats was by the method of Moyle \& Ramachandran (1973) using collagenase (Type 1; Sigma) at $0.25 \mathrm{mg} / \mathrm{ml}$ and $1 \mathrm{ml} /$ testis; dispersion of testicular tissue was effected by incubation for $20 \mathrm{~min}$ at $37^{\circ} \mathrm{C}$ in a shaking water bath ( 100 cycles/min).

The significance of differences between means was assessed by Student's $t$ test.

\section{Results}

\section{Interstitial fluid accumulation}

Compared to controls, injection of 22-day-old rats with 1 or 0.1 i.u. hCG had only minor effects on the recoverable amounts of interstitial fluid at $20 \mathrm{~h}$ after injection, whilst treatment with 10 i.u. hCG increased fluid levels 20 -fold at this time (Table 1); at $48 \mathrm{~h}$ after treatment with these doses of hCG, interstitial fluid values were not different from those of controls (Table 1). Testis weight and recoverable interstitial fluid increased with increase of age in control rats (Table 2) and at each age injection of $170 \mathrm{i} . \mathrm{u} . \mathrm{hCG} / \mathrm{kg}$ significantly increased testis weight $20 \mathrm{~h}$ later; depending on age, between 56 and $99 \%$ of this change could be accounted for by increased amounts of interstitial fluid (Table 2).

\section{Interstitial fluid composition}

The concentration of testosterone in interstitial fluid from pubertal (50- and 70-day-old) control rats was 3-4 times higher than the levels in adult (200-day-old) rats, and a similar pattern was evident following injection of hCG, although this treatment significantly increased the fluid concentration of testosterone at each age (Table 2). 
Table 1. Accumulation of interstitial fluid (mean \pm s.d.) in the testes of 22-day-old rats (4/group) at $20 \mathrm{~h}$ and $48 \mathrm{~h}$ after injection of various doses of hCG

\begin{tabular}{ccc}
\hline $\begin{array}{c}\text { Dose of hCG } \\
\text { injected (i.u.) }\end{array}$ & $\begin{array}{c}\text { Time when } \\
\text { killed (h) }\end{array}$ & $\begin{array}{c}\text { 'Interstitial } \\
\text { fluid' (mg) }\end{array}$ \\
\hline O(control) & 20 & $5.0 \pm 6.6$ \\
10 & & $107.5 \pm 22.5^{\text {*** }}$ \\
1 & & $11.5 \pm 10.8$ \\
0.1 & & $16.3 \pm 6.2^{*}$ \\
10 & 48 & $7.5 \pm 6.2$ \\
1 & & $5.0 \pm 7.6$ \\
0.1 & & $8.5 \pm 6.5$ \\
\hline
\end{tabular}

Significantly different from control value, $* P<0.05 ;{ }^{* * *} P<0.001$.

Table 2. Testicular weight, 'interstitial fluid' and binding of ${ }^{125}$ I-labelled hCG in rats of different ages at $20 \mathrm{~h}$ after injection of saline or $170 \mathrm{i} . \mathrm{u} . \mathrm{hCG} / \mathrm{kg}$

\begin{tabular}{cllccc}
\hline $\begin{array}{c}\text { Age } \\
\text { (days) }\end{array}$ & Treatment & $\begin{array}{c}\text { Paired testis } \\
\text { weight }(\mathrm{mg})\end{array}$ & $\begin{array}{c}\text { 'Interstitial fluid' } \\
(\mathrm{mg} / \mathrm{paired} \text { testes) }\end{array}$ & $\begin{array}{c}\text { Testosterone in } \\
\text { interstitial fluid' } \\
(\mathrm{ng} / \mathrm{ml})\end{array}$ & $\begin{array}{c}\text { Binding of } \\
\text { 12s I-labelled hCG } \\
(\mathrm{pg} / 20 \mathrm{mg})\end{array}$ \\
\hline \multirow{2}{*}{35} & Saline & $802 \pm 84$ & $44 \pm 7$ & - & $99 \cdot 2 \pm 15 \cdot 0$ \\
& hCG & $953 \pm 69^{*}$ & $193 \pm 24^{* * *}$ & $384 \cdot 4 \pm 43 \cdot 9$ & $39 \cdot 2 \pm 5 \cdot 0^{* * *}$ \\
50 & Saline & $1966 \pm 78$ & $158 \pm 24$ & $245 \cdot 5 \pm 57 \cdot 8$ & $272 \cdot 6 \pm 42 \cdot 2$ \\
& hCG & $2131 \pm 92^{*}$ & $250 \pm 21^{* *}$ & $767 \cdot 5 \pm 22 \cdot 8^{* * *}$ & $127 \cdot 4 \pm 19 \cdot 0^{* * *}$ \\
70 & Saline & $2459 \pm 96$ & $192 \pm 42$ & $264 \cdot 7 \pm 101 \cdot 7$ & $425 \cdot 7 \pm 56 \cdot 2$ \\
& hCG & $2689 \pm 76^{* * *}$ & $338 \pm 42^{* * *}$ & $519 \cdot 5 \pm 125 \cdot 7^{* *}$ & $209 \cdot 9 \pm 81 \cdot 6^{* * *}$ \\
& Saline & $2898 \pm 235$ & $360 \pm 61$ & $67 \cdot 1 \pm 17 \cdot 7$ & $389 \cdot 9 \pm 72 \cdot 1$ \\
& hCG & $3235 \pm 213^{*}$ & $581 \pm 97^{* * *}$ & $332 \cdot 0 \pm 74 \cdot 7^{* * *}$ & $176 \cdot 5 \pm 34 \cdot 3^{* * * *}$ \\
\hline
\end{tabular}

Results are the mean \pm s.d. of 4-7 animals in each group.

Significantly different from respective control value, ${ }^{*} P<0.05 ;{ }^{* *} P<0.01 ;{ }^{* * *} P<0.001$.

The concentration of various non-hormonal factors in serum and interstitial fluid, collected $16 \mathrm{~h}$ after injection of 25 -day-old rats with $10 \mathrm{i}$.u. hCG, is shown in Table 3 . The protein content and concentrations of sodium and calcium in interstitial fluid were similar to those found in serum whereas the concentrations of potassium and phosphate ions were higher than those in serum.

Table 3. A comparative analysis of serum and 'interstitial fluid' from hCG-treated immature rats

\begin{tabular}{lcc}
\hline & Serum & 'Interstitial fluid' \\
\hline Sodium (mmol/l) & 141 & 140 \\
Potassium (mmol/l) & $5 \cdot 7$ & $14 \cdot 7$ \\
Calcium $(\mathrm{mmol} / \mathrm{l})$ & $2 \cdot 56$ & $2 \cdot 85$ \\
Phosphate $(\mathrm{mmol} / \mathrm{l})$ & $2 \cdot 24$ & $3 \cdot 85$ \\
Total protein $(\mathrm{mg} / \mathrm{ml})$ & 54 & 49 \\
Albumin $(\mathrm{mg} / \mathrm{ml})$ & 42 & 41 \\
Urea $(\mathrm{mmol} / \mathrm{l})$ & $5 \cdot 0$ & $5 \cdot 4$ \\
Urate $(\mathrm{mmol} / \mathrm{l})$ & $0 \cdot 14$ & $0 \cdot 75$ \\
Alkaline phosphatase (units/l) & 570 & 454 \\
Aspartate aminotransferase (units/l) & 190 & 1230 \\
\hline
\end{tabular}

Analyses are based on a pool of material collected over a 30-min period from the testes of eight 25 -day-old rats killed $16 \mathrm{~h}$ after injection of 10 i.u. hCG. 


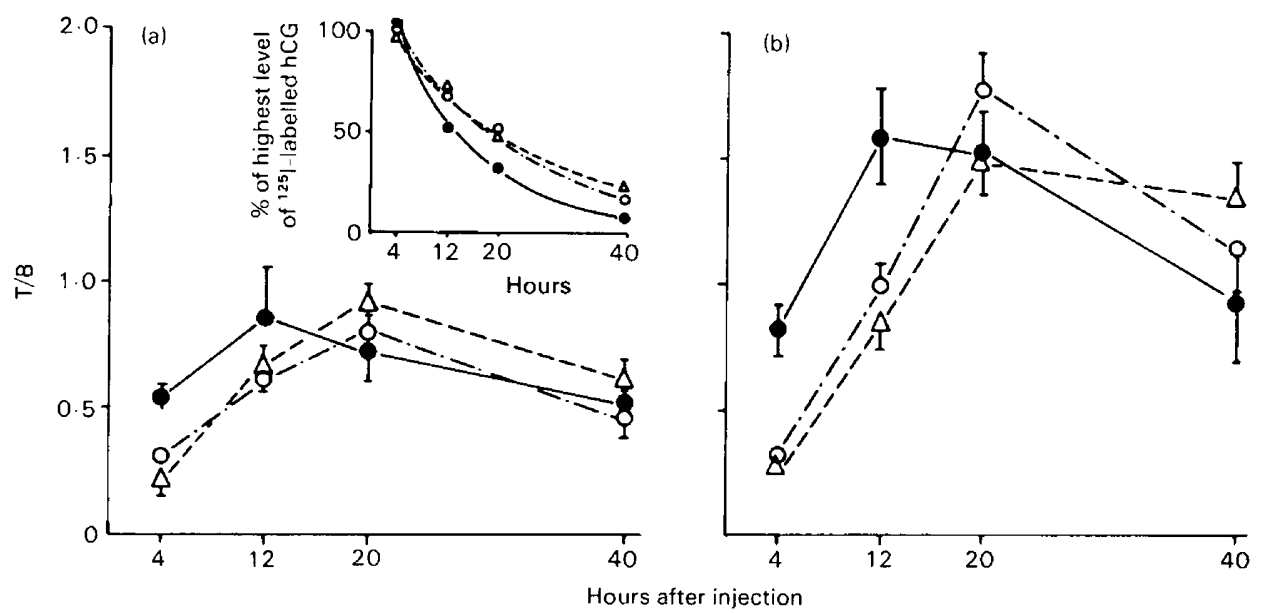

Text-fig. 1. Age-dependent changes in the uptake of ${ }^{125} \mathrm{I}$-labelled hCG in vivo by rat testes (a) after injection of $10 \mathrm{ng}{ }^{125}$ I-labelled hCG and (b) after injection of $10 \mathrm{ng}{ }^{125} \mathrm{I}$-labelled hCG +10 i.u. unlabelled hCG. Results are plotted as the ratio of c.p.m. radioactivity per $\mathrm{mg}$ testis divided by c.p.m. radioactivity per $\mathrm{mg}$ blood (T/B). The inset shows disappearance curves for ${ }^{125} \mathrm{I}$ labelled $\mathrm{hCG}$ in blood. $\longrightarrow, 25$-day-old rats; $\mathrm{O}-\mathrm{O}, 60$-day-old rats; $\triangle---\triangle, 120$ day-old rats. Values are the mean \pm s.d. for 3 animals at each point.

\section{Binding of ${ }^{125}$ I-labelled $h C G$}

In control rats, in-vitro testicular binding of ${ }^{125} \mathrm{I}$-labelled hCG increased 4-fold between 35 and 70 days of age when adult levels were reached, whilst injection of hCG reduced this binding by 50 to $60 \%$ at each age (Table 2 ).

In vivo, the ratio of radioactivity in the testes to that in the blood (T/B) after injection of 10 ng ${ }^{125}$ I-labelled hCG, increased $(P<0.01)$ between 4 and $12 \mathrm{~h}$ in 25 -day-old rats and between 4 and $20 \mathrm{~h}$ in $60-$ and 120 -day-old rats and then declined gradually (Text-fig. 1a). In comparison, injection of 10 i.u. unlabelled hCG $+10 \mathrm{ng}{ }^{125}$ I-labelled hCG (0.12 i.u.) resulted in a similar pattern of uptake but with a doubling $(P<0.01)$ of the T/B ratio of radioactivity at 12 and $20 \mathrm{~h}$ in all three age groups (Text-fig. 1b); this occurred despite the effective dilution of circulating levels of ${ }^{125}$ I-labelled hCG by a factor of $1: 80$. Blood levels of ${ }^{125}$ I-labelled hCG were highest at $4 \mathrm{~h}$ after injection and then declined with a half-life of approximately $12 \mathrm{~h}$ (25-day-old rats) or 20 $\mathrm{h}$ (60- and 120-day-old rats). In another experiment in which 25-day-old male rats were killed 16 $\mathrm{h}$ after injection of $10 \mathrm{i}$.u. unlabelled hCG $+10 \mathrm{ng}{ }^{125}$ I-labelled hCG, the ratio of radioactivity in interstitial fluid to that in the blood was $1.13 \pm 0.08$ (mean \pm s.d., $N=5$ ) whereas in the same rats the testis tissue:blood ratio was significantly higher $(P<0.001)$ at $2.78 \pm 0.51$.

\section{'Adhesiveness'}

The preparation of testicular homogenates for receptor-binding studies (Sharpe, 1976) involves resuspension of a sedimented pellet in buffer. This is normally achieved simply by vortexing for 5-10 sec but the pellet failed to resuspend when tissue was taken at 12,16, 20 and $24 \mathrm{~h}$ from 21-day-old rats after injection ( $\mathrm{N}=3$ or 4 at each time) of 10 i.u. hCG and only partly resuspended at 6 and $8 \mathrm{~h}$ after injection. Resuspension was normal by $30 \mathrm{~h}$ after injection.

The preparation of isolated Leydig cells using collagenase results in cell dispersion within 20 min when testes of immature control rats are used. In contrast the testes from 4 rats killed $20 \mathrm{~h}$ after injection of 10 i.u. hCG remained completely intact even after $45 \mathrm{~min}$ incubation with collagenase, and similarly at $20 \mathrm{~h}$ after injection of 4 i.u. hCG, minimal dispersion of the 
testicular tissue was achieved. At $40 \mathrm{~h}$ after injection of $10 \mathrm{i} . \mathrm{u}$. hCG normal testicular dispersion was achieved by 20 min of incubation with collagenase.

\section{Discussion}

Most reports concerning testicular fluid in the literature refer to rete testis fluid which is believed to be secreted by Sertoli cells into the lumen of the seminiferous tubules (see Waites \& Setchell, 1969; Setchell, 1970). The testicular fluid described in the present paper is referred to as 'interstitial fluid' as this is presumably where it accumulates in the testis. Using techniques similar to those presently used, Pande, Chowdhury, Dasgupta, Chowdhury \& Kar (1966) collected fluid from the untreated rat testis and considered it to represent testicular lymph, which normally fills the interstitial spaces of the rat testis (see Fawcett, Neaves \& Flores, 1973). Although the composition of 'interstitial fluid' appears similar to that described for testicular lymph (Pande $e t$ al., 1966; Setchell, 1970), it has a much higher concentration of potassium; this may be a consequence of cell damage (perhaps indicated by the high level of aspartate aminotransferase) or leakage of the ion from the seminiferous tubules, as the level of potassium found was similar to that reported for rete testis fluid (Setchell, 1970). However, in other respects, 'interstitial fluid' and rete testis fluid appear quite different. Firstly, the latter has very low levels of protein and phosphate in relation to serum (Setchell, 1970) whereas 'interstitial fluid' has a similar protein content and an elevated level of phosphate compared to serum. Secondly, whereas hCG stimulates the accumulation of 'interstitial fluid' it has been reported to have either no effect (Setchell, Duggan \& Evans, 1973) or to reduce the flow rate of rete testis fluid at 12 to $24 \mathrm{~h}$ after injection (Laporte \& Dacheux, 1977a, b). Thirdly, the concentration of testosterone in 'interstitial fluid' from rats of different ages treated with hCG was in the range $300-800 \mathrm{ng} / \mathrm{ml}$ which is considerably higher than the levels reported by Harris \& Bartke (1974) for rete testis fluid in rats treated with hCG, but is similar to values reported in interstitial fluid obtained by micropuncture of the rat testis (Comhaire \& Vermeulen, 1976).

It has previously been shown (Sharpe, 1977b) that injection of immature rats with 10 i.u. hCG led to no increase in 'interstitial fluid' until after $6 \mathrm{~h}$ with levels peaking at 12-20 h and falling to control levels by $40 \mathrm{~h}$ after injection. The present data also show fluid accumulation at $20 \mathrm{~h}$ after injection of $170 \mathrm{i} . \mathrm{u} . \mathrm{hCG} / \mathrm{kg}$ and, in addition, demonstrate that at 12 to $20 \mathrm{~h}$ after injection of $10 \cdot 12$ i.u. hCG (10 i.u. unlabelled plus 0.12 i.u. ${ }^{125}$ I-labelled hCG) there is a doubling of the testis/blood ratio of ${ }^{125} \mathrm{I}$-labelled hCG compared to that found following injection of 0.12 i.u. ${ }^{125} \mathrm{I}$-labelled hCG only. This change is due mainly to increased binding of ${ }^{125} \mathrm{I}$-labelled hCG to testis tissue rather than to its accumulation in 'interstitial fluid' because the ratio of radioactivity in the latter to that in the blood was near to unity whilst the testis tissue:blood ratio was 2.78. This hCG-induced increase in the testicular binding of hCG has been reported previously for immature rats (Sharpe, 1976) but its precise cause is unknown. It seems most likely that it results from changes such as increased capillary wall permeability or increased testicular blood flow and the findings of Hartman, Millman \& Stavorski (1950) would support this view. It may be this change which results in the accumulation of 'interstitial fluid', although the presently observed increase in 'adhesiveness' of homogenized testis tissue between 8 and $20 \mathrm{~h}$ after injection of immature rats with $10 \mathrm{i} . \mathrm{u}$. hCG is suggestive of some other change occurring. The fact that, at $20 \mathrm{~h}$ after hCG injection, testis tissue failed to disperse with collagenase suggests that this change might be ionic, and the very high concentrations of potassium and phosphate in 'interstitial fluid' are perhaps significant in this respect.

At $20 \mathrm{~h}$ after injection of hCG, when interstitial fluid accumulation is near maximal, there are two other important effects of this hormone on the testis. Firstly, there is a reduction in the invitro testicular binding of ${ }^{125} \mathrm{I}$-labelled $\mathrm{hCG}$ which is related, at least in part, to a loss of $\mathrm{LH}$ (hCG) receptors (Hsueh et al., 1976, 1977; Sharpe, 1976) and secondly, there may be a $50 \%$ 
decrease in the stimulatable capacity of the testis to secrete testosterone (Hsueh et al., 1977; Sharpe, 1977a). It is especially interesting that the latter effect only occurs (in the immature rat) with doses of 10 i.u. hCG or more, precisely the dose which causes major accumulation of 'interstitial fluid'. It is also relevant that in the cryptorchid adult rat, in which serum levels of $\mathrm{LH}$ are 3-4 times higher than normal, as much as $50 \%$ of testicular weight may be accounted for by 'interstitial fluid' containing high levels of testosterone (Sharpe, Kerr \& de Kretser, 1978).

The hCG-induced accumulation of 'interstitial fluid' in the immature rat testis can be inhibited by cycloheximide, a treatment which also interfers with the induced loss of LH receptors (Sharpe, 1977b). This raises the possibility that these two effects of hCG may be dependent on the synthesis of the same protein(s). However, in contrast to the hCG-induced accumulation of 'interstitial fluid', LH receptor loss persists for long periods (Hsueh et al., 1976; Sharpe, 1976), is not maximal until 2 days after treatment (Hsueh et al., 1977) and occurs even with very small doses of hCG (Sharpe, 1976) which, as shown here, do not result in major accumulation of 'interstitial fluid'. It is possible that hCG-stimulation of the testis always results in the formation of 'interstitial fluid' and it is simply the balance between formation and clearance that determines whether this fluid accumulates in measurable quantities. It seems clear that a better understanding of the causes of 'interstitial fluid' accumulation will also increase our understanding of $\mathbf{L H}$ receptor regulation and associated changes in steroidogenic function as all three factors are, at least initially, determined by the same gonadotrophic stimulus.

I am grateful to Dr A. S. McNeilly for helpful advice and to the NIAMDD, U.S.A., for purified hCG.

\section{References}

Comhaire, F.H. \& Vermeulen, A. (1976) Testosterone concentration in the fluids of seminiferous tubules, the interstitium and the rete testis of the rat. $J$. Endocr. 70, 229-235.

Corker, C.S. \& Davidson, D.W. (1978) Radioimmunoassay of testosterone in various biological fluids without chromatography. J. Steroid Biochem. 9, 373-374.

de Jong, F.H. \& Sharpe, R.M. (1977) The onset and establishment of spermatogenesis in rats in relation to gonadotrophin and testosterone leveis. J. Endocr. 75, 197-207.

Fawcett, D.W., Neaves, W.B. \& Flores, M.N. (1973) Comparative observations on intertubular lymphatics and the organization of the interstitial tissue of the mammalian testis. Biol. Reprod. 9, 500532.

Haour, F. \& Saez, J.M. (1977) hCG-dependent regulation of gonadotropin receptor sites: negative control in testicular Leydig cells. Molec. cell. Endocr. 7, 17-24.

Harris, M.E. \& Bartke, A. (1974) Concentration of testosterone in testis fluid of the rat. Endocrinology 95, 701-706.

Hartman, C.G., Millman, N. \& Stavorski. J. (1950) Vasodilation of the rat testis in response to hCG. Fert. Steril. 1, 443-452.

Hsueh, A.J.W., Dufau, M.L. \& Catt, K.J. (1976) Regulation of luteinizing hormone receptors in testicular interstitial cells by gonadotropin. Biochem. Biophys. Res. Commun. 72, 1145-1152.
Hsueh, A.J.W., Dufau, M.L. \& Catt, K.J. (1977) Gonadotropin induced regulation of luteinizing hormone receptors and desensitization of $3^{\prime}: 5^{\prime}$-cyclic AMP and testosterone responses. Proc. natn. Acad. Sci., U.S.A. 74, 592-595.

Laporte, E. \& Dacheux, J.-L. (1977a) Influence d'une injection d'hormone chorionique (HCG) sur l'accumulation du fluide testiculaire après ligature du vas efferens chez le rat Wistar adulte. C. r. hebd. Séanc. Acad. Sci., Paris D 285, 241-244.

Laporte, E. \& Dacheux, J.-L. (1977b) Effect of hCG injection on testicular fluid production by the adult rat. IRCS Med. Sci. 5, 355.

Miyachi, Y., Vaitukaitis, J.L., Nieschlag, E. \& Lipsett, M.B. (1972) Enzymatic radioiodination of gonadotropins. J. clin. Endocr. Metab. 34, 23-28.

Moyle, W.R. \& Ramachandran, J. (1973) Effect of LH on steroidogenesis and cyclic AMP accumulation in rat Leydig cell preparations and mouse tumor Leydig cells. Endocrinology 93, 127-134.

Pande, J.K., Chowdhury, S.R., Dasgupta, P.R., Chowdhury, A.R. \& Kar, A.B. (1966) Biochemical composition of the rat testis fluid. Proc. Soc. exp. Biol. Med. 121, 899-902.

Purvis, K., Torjesen, P.A., Haug, E. \& Hansson, V. (1977) hCG suppression of LH receptors and responsiveness of testicular tissue to hCG. Molec. cell. Endocr. 8, 73-80.

Setchell, B.P. (1970) Testicular blood supply, lymphatic drainage and secretion of fluid. In The Testis, Vol. 1, pp. 101-239.Eds A. D. Johnson, W. R. Gomes \& N. L. VanDenmark. Academic Press, New York. 
Setchell, B.P., Duggan, M.C. \& Evans, R.W. (1973) The effect of gonadotrophins on fluid secretion and sperm production by the rat and hamster testis. J. Endocr. 56, 27-36.

Sharpe, R.M. (1976) hCG-induced decrease in availability of rat testis receptors. Nature, Lond. 264, 644-646.

Sharpe, R.M. (1977a) Gonadotrophin-induced reduction in the steroidogenic responsiveness of the immature rat testis. Biochem. Biophys. Res. Commun. 76, 957962.
Sharpe, R.M. (1977b) Relationship between testosterone, fluid content and luteinizing hormone receptors in the rat testis. Biochem. Biophys. Res. Commun. 75, 711717.

Sharpe, R.M., Kerr, J.B. \& de Kretser, D.M. (1978) Studies on Leydig cell function in cryptorchid rats. Endocrinology 102A, Abstract No. 594.

Waites, G.M.H. \& Setchell, B.P. (1969) Physiology of the testis, epididymis and scrotum. Adv. Reprod. Physiol. 4, 1-63.

Received 15 June 1978 